DOI: $10.14451 / 2.150 .21$

\title{
ИНСТИТУЦИОНАЛЬНЫЙ МЕТОД В ГОСУДАРСТВЕННО-ПРАВОВЫХ ИССЛЕДОВАНИЯХ
}

\author{
(c) 2020 Осипов Владимир Сергеевич \\ доктор экономических наук, профессор \\ МГИМО МИД России, Москва \\ E-mail:vs.ossipov@inno.mgimo.ru
}

В статье предлагается новый метод научного познания в государствоведении как юридической науке - институциональный метод. Институциональный метод государственно-правовой науки это специальный, реальный, комплементарный, синтетический, структурно-функциональный метод правовой науки, служащий для определения нормативного и фактического объёма полномочий аппарата государства и его отдельных частей, ветвей власти, отдельных учреждений и персоналий, обличенных властью (должностей) и связей между ними. Цель исследования состоит в обосновании и определении нового метода на основе достижений институциональной теории в смежных с юриспруденцией науках - экономике, политологии, социологии.

На основании предложенного институционального метода в государственно-правовой науке или государствоведении предложена эволюционная модель изменения форм государства с позиции структурно-функционального подхода.

Ключевые слова: институциональный метод, государствоведение, эволюция форм государства

Хорошо известно, что институциональная теория междисциплинарна и применима для всех общественных наук, так как с самого своего зарождения ее развитием занимались правоведы, экономисты и социологи. Так, работы Джона Коммонса находятся на стыке юридической и экономической науки [1]: «настоящий труд является в основе своей теоретическим, он оперирует понятиями, заимствованными из решений английских и американских судов, хотя при этом не упускаются из вида понятия ведущих экономистов от физиократов до современности» [2]. Работы Л. Гумпловича [3], Г. Еллинека [4], В. Вильсона [5] носят явно междисциплинарный общественно-научный характер.

Вклад М.Ориу [6] и Л.Дюги [7], а также их последователей - представителей французской школы юридического институционализма (А.Эсмен, Д.Ренар, Ж.Баландье, Ж.Бурдье, Ж.-Л.Бержель) в развитие институциональной государственно-правовой науки сложно переоценить. Важно отметить вклад дореволюционной российской государственно-правовой школы в развитии институциональной теории государствоведения. Здесь ярко выделяются имена М.М.Ковалевского, Н.Н.Алексеева, А.Д.Градовского, В.Грибовского, Н.И.Кареева, Н. М. Коркунова, Д. М. Петрушевского, П.Б.Струве, Б.Н.Чичерина и другие. Советская и совре- менная российская школы теории государства и права, несмотря на этатистский уклон, дала существенный вклад в развитие институциональной теории государствоведения, который представлен именами И.Д.Левина, В.Е. Чиркина, В.Д.Зорькина, В.Я.Любашица, В.А.Туманова, И. Л. Честнова, В. А. Четвернина и других.

Советский теоретик государства И.Д.Левин отмечал, что «государство есть само право в институциональном аспекте... для определения государства главную роль играет не нормативный, а институциональный аспект права» [8]. В этом кроется важное разделение права и государства при всем единстве понятий. Мы согласны с И.Д.Левиным, так как именно не совокупность норм права составляет собой государство, но реальное воплощение норм, совокупность учреждений, процедур и взаимосвязей между ними.

Возникает сложная задача определения метода исследования государства, так как исследование причинно-следственных связей, например, в вопросе о распаде государстве, очень важное значение имеет изучение реальных событий и их сопоставление с нормативным порядком. Как отмечал Р.Лукич [9] реальные события сказываются на методологии исследования причинно-следственных связей, поскольку они изменяются не только под действием других реальных явлений - их изменения могут быть вы- 
званы внутренними причинами, которые также требуют изучения. Изменчивость рассматриваемых событий выражает их важнейшие свойства, для чего и необходимо свой специальный метод познания изучаемых явлений, так как институциональная теория предполагает изучение явлений в их динамике и сопоставлении с нормативным порядком.

Право - это не только социальное, но и политическое явление, особая разновидность социальных явлений [10]. Такая позиция позволяет нам обратиться к смежным общественным наукам и выяснить, как используется институциональный метод в экономической теории и политологии. Например, социология права утверждает, что эффективность права в изменении шаблонов поведения не находится в полной зависимости ни от той степени, в которой оно соответствует господствующим в сообщности установкам, ни от строгости санкций, применяемых для проведения норм права в жизнь [11]. Эта важная мысль, которую мы разделяем, свидетельствует о том, что существующих методов исследования в юридической науке государствоведения недостаточно, но они присутствуют в смежных общественных науках.

Институциональный метод широко используется в экономической теории и политологии, что может дополнить существующие, но несколько устаревшие методы юридической науки в направлении исследования проблематики государствоведения, а также объяснения необходимости обособления государствоведения как отдельной науки, то есть институциональный метод в смежных науках используется как специальный, реальный, структурно-функциональный метод познания соответствующих явлений. Таким образом, принимая во внимание, что теория государства и права относится к общественным наукам, нам представляется возможным использовать институциональный метод для исследования государства как правового явления.

$\mathrm{K}$ разработке институционального метода юридической науки государствоведения ранее уже подходили некоторые ученые, однако, на наш взгляд, его разработка не достигла главной цели в преодолении недостатков цивилистического и эволюционного подходов, с одной стороны, и формационного подхода, классификации государств и стадий их развития, включая стадию разрушения, разложения, распада, упадка государства, с другой стороны. Послед- нее особенно важно, так как эта стадия развития государства представлена в научной литературе крайне фрагментарно, а в государственноправовой научной литературе и того меньше.

Следует отметить, что институциональный метод юридической науки государствоведения разрабатывается нами на основе способов, приемов, которые первоначально были разработаны представителями неюридических наук, а, следовательно, институциональный метод юридической науки государствоведения следует отнести к группе специальных методов правовой науки [12]. Кроме того, мы придерживаемся социологического понимания права в духе О.Эрлиха, который считает, что нормы права применяются не потому, что государство их предписывает и санкционирует, а потому что они коренятся в самих условиях жизни общества. Подлинное право, живое право, социальное право состоит из норм, осуществляющихся в реальной действительности [13].

К правовым методам в публичном праве Чиркин В.Е. [14] предлагал относить те, которые основаны на конституции, законах, иных правовых актах, в пределах и в соответствии с процедурой, установленной ими. Так, среди правовых форм различают законодательствование, управление, правосудие, контроль. Законодательствование - это установление правил наиболее общего характера по важнейшим вопросам общественной жизни, определяющих поведение и деятельность физических и юридических лиц, организаций, учреждений, предприятий, коллективов и т.д. Согласимся с В.Е.Чиркиным, ведь именно установление правил представляет собой введение института, причем тех правил, которые определяют поведение лиц в правоотношениях. Управление - исполнительно-распорядительная, организационная деятельность государства, публичных коллективов, их органов, должностных лиц. Здесь мы можем увидеть «процедурную» сторону института государства. Правосудие - деятельность суда от имени государства в особой процессуальной форме по разрешению конфликтов, возникающих между гражданами, органами государства, физическими и юридическими лицами. Применение легального насилия для предотвращения или наказания виновного в противоправном действии и есть главная функция государства по обеспечению прав и свобод гражданина и человека. Контрольная деятель- 
ность органов публичного управления выражается в форме инспектирования, проверки соответствия деятельности органов государства, должностных лиц законам, актам вышестоящих органов, путем проверки выполнения должностных обязанностей, соблюдения установленных стандартов, правил. Следование правилам, установленных с помощью законодательствования, должно привести к правомерному поведению лиц, достижению ими своих целей. Государство в лице контролирующих органов способствует тому, чтобы лица следовали установленным правилам и не нарушали своими действиями прав других лиц. Неправовые (но не противоправные) формы и методы публичного управления это повседневная организационно-техническая, оперативная деятельность, неурегулированная детально процедурно правом. Отсюда следует, что институциональный метод в юридической науке - это специальный, реальный, комплементарный, синтетический, структурнофункциональный метод правовой науки, служащий для определения нормативного и фактического объёма полномочий аппарата государства и его отдельных частей, ветвей власти, отдельных учреждений и персоналий, обличенных властью (должностей) и связей между ними.

Институциональной метод в юридической науке и в государствоведении, в частности, позволяет оценить нормативное и фактическое содержание прав и обязанностей организаций, учреждений, соотношение норм позитивного и фактического права, а также процедуры, которые формируют аппарат государства. Именно институциональная теория государства выявляет тенденцию усиления исполнительной власти и её доминирования за счёт процедур, норм и учреждений, с помощью которых происходит избрание/назначение на должности руководителей судебной и законодательной ветвей власти. Следует отметить, что одним из следствий такого усиление исполнительной власти становится ветократия*. Институциональный метод юридической науки позволяет оценить систему сдержек и противовесов в развитых демократиях и новых автократиях и выявить «болезни» [15] государства, среди которых выделяют, в том числе нелигитимное насилие власти над несогласными, идеологическое единомыслие, фактическое недопущение части населения к процессу принятия решений (de jure всенародное принятие конституции оборачивается ее принятием de facto подавляющим меньшинством), коррупция, персонификация власти и др.

За счет своего структурно-функционального содержания (формы) институциональный метод юридической науки доказывает необходимость возрождения науки государственного права (государствоведения) для приостановления хаотических изменений в системе государственного управления, корректировки процессов государственного строительства с целью поиска нового баланса сил среди ветвей власти, поиска способов избавления от ветократических процедур сдерживания судебной и законодательной ветвей власти в реализации их полномочий по защите прав граждан судами, а также реализации наказов и чаяний избирателей перед выборами в законодательный орган.

Институциональный метод юридической науки позволяет выявить дисбаланс нормативного и фактического в праве и оценивает степень влияния этого дисбаланса на государство и его форму, что оказывает существенное влияние на правоотношения граждан и государства и органов государства между собой.

Возвращается методологическая задача определения самой возможности существования общей теории государства и права, необходимости обращения к дореволюционной российской и современной зарубежной традиции разделения правоведения и государствоведения на две различные юридические науки. Принятие синтетической, общей, единой теории государства и права с общим объектом, предметом и методологией в советский период согласовывалось с этатистской, позитивистской, легистской установкой на подчинение права государству. Понимание того факта, что этатистская, легистская, позитивистская концепции права все же признают государство элементом сферы права, позволяло объединить в одну теорию две категории государства и права при примате государства. Разрешить указанное противоречие при-

\footnotetext{
* Ф. Фукуяма выдвинул идею наступления эры ветократии, то есть когда право вето становится самым главным при разработке и принятия решений, отчего решения не принимаются вовсе. Совокупность взаимосвязанных институтов мешает принимать решения, так как количество налагаемых ими ограничений слишком велико, отчего власти предпочитают не принимать решений вовсе (Fukuyama, F. Oh for a Democratic Dictatorship and not a Vetocraty // Financial Times. 2011. 22nd November)
} 
звана институциональная теория государства.

Снятие идеологического налета позитивизма и юснатурализма с науки теории государства и права позволяет с помощью институционального метода юридической науки показать структурно-функциональную несостоятельность, искусственность соединения двух наук,государствоведения и правоведения,- теории государства и государственного строительства, и теории права. Разделение общей теории государства и права способно дать новые импульсы в развитии обеих юридических наук, так как «чистые» теории права и государства окажутся раскованными идеологическими рамками друг друга.

Разница в позитивном предписании и реальном исполнении норм права и социальных норм, нормативного и фактического объёма прав и обязанностей (полномочий) организаций и учреждений, комплементарность процедур могут быть определены с помощью институционального метода юридической науки государствоведения. Институциональный метод юридической науки выявляет процедуры, которые способствуют укоренению дисбаланса власти в ее ветвях, что особенно ярко стало выявляться в наше время с усилением исполнительной власти. Отсюда и возможные злоупотребления властью со стороны органов исполнительной власти и их представителей, так как процедурно исполнительная власть оказалась «сильнее» судебной и законодательной ветвей власти. Укорененность привычки иметь «сильного» главу исполнительной власти способствует развитию ветократии в авторитарных режимах.

Институциональный метод юридической науки позволяет проследить эволюцию государства и по-новому определить его формы в соответствии со структурно-функциональным содержанием. Так, мы предлагаем выделить личностное харизматическое государство, когда в догосударственных сообществах появляется сильный лидер племени и сосредотачивает в своих руках фактическую политическую власть, определяя и состав народонаселения (племени), его территориальное рассредоточение и организацию управления. Следующая форма добавляет к прежней принцип династического наследования власти, а принцип получения власти наиболее сильным постепенно отмирает, так как на его место приходит родовая семейная традиция. Сословно-представительное государство обогащается совещательным органом власти при государе. Новый орган управления обладает ограниченными полномочиями, а включаются в него лишь наиболее выдающиеся по родовитости и имущественному положению представители нации. Народно-представительное государство обогащается всеобщими избирательными правами и выборами законодательного органа власти, а также в некоторых случаях главы исполнительной власти. Партийно-представительное государство характерно для тоталитарных и авторитарных режимов. Как отмечает Дж.Ганди «использование единственной партии для управления государством широко применялось гражданскими диктаторами во всем развивающемся мире. После получения независимости однопартийные системы возникли в 60\% государств тропической Африки» [16]. Следует отметить, что партийно-представительное государство может быть установлено и в формальных демократических республиках. Так, политическая деятельность в англо-саксонских странах зачастую олигополизирована двумя партиями, которые чередуются электоральными циклами. Частично прямо демократическое государство характеризуется не только электоральными циклами, когда политическая активность возрастает и снижается в зависимости от сроков выборов, но проявляется в более широком использовании плебисцитов для решения важных вопросов внутренней и внешней политики.

Настоящей статьей мы открываем дискуссию о возможных направлениях использования институционального метода юридической науки в государствоведении и правоведении.

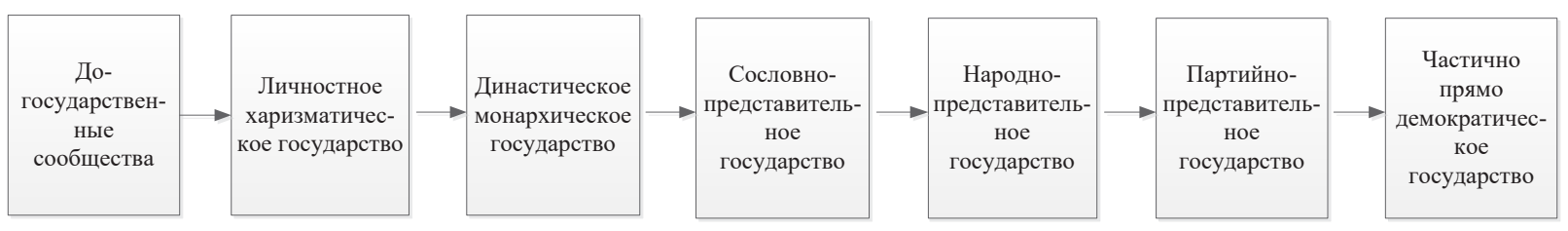

Рисунок 1. Эволюция форм государства при применении институционального метода юридической науки государствоведения 


\section{Библиографический список}

1. Commons, J.R. Institutional Economics. Its Place in Political Economy. Madison: The University of Wisconsin Press, 1959. - 921 p.; Commons, J. R. Legal Foundations of Capitalism. New York: The Macmillan Company, 1924._-394 p.

2. Commons, J.R. Legal Foundations of Capitalism. New York: The Macmillan Company, 1924. Introduction. Цит. по Коммонс Дж.Р.Правовые основания капитализма. М.: ИД ВШЭ, 2011. С. 9.

3. Гумплович, Л. Основы социологии. СПб.: Книжный магазин и склад изданий О.Н. Поповой, 1899. - 362 с.

4. Еллинек, Г. Общее учение о государстве. СПб.: Издание товарищества «Общественная польза», 1903. - 532 с .

5. Вильсон, В.Государство. Прошлое и настоящее конституционных учреждений. М.: Издание В. М. Саблина, 1905.- 560 c.

6. Ориу, М. Основы публичного права. М.: Издательство Коммунистической академии, 1929.- 760 с.

7. Дюги, Л. Конституционное право. Общая теория государства. М.: Типография Т-ва И. Д. Сытина, 1908. - 958 с.; Дюги, Л. Общество, личность и государство. Социальное право, индивидуальное право и преобразование государства. СПб.: Издательство «Вестника знания» (В.В.Битнера), 1914. - 54 с.

8. Левин, И. Д. Современная буржуазная наука государственного права. М.: Изд-во АН СССР, 1960. С. 183.

9. Лукич, Р. Методология права. М.: Прогресс, 1981. С.93

10. Там же, с. 127

11. Мейхью, Л. Социология права. В кн. Американская социология: перспективы, проблемы, методы / Под ред. Г. В. Осипова. М.: Издательство «Прогресс», 1972. С. 230.

12. Сырых, В. М. История и методология юридической науки. М.: Издательство НОРМА, 2012. С. 96.

13. Эрлих, О., Основоположение социологии права. СПб.: ИД СПбГУ, 2011. - 704 с.

14. Чиркин, В.Е. Публичное управление. М.: Юрист, 2004. С.48-50.

15. Куриц, С.Я., Воробъев, В.П.Болезни государства. Диагностика патологий системы государственного управления и конституционного права. М.: ООО «Национальное собрание», 2010.- 504 с.

16. Ганди, Дж. Диктатуры и их институты: особый мир // Неприкосновенный запас. Дебаты о политике и культуре. 2016. № 108 H3 4. 